blank reactions. Ann. clin. Biochem., 8, 189-194.

Hirst, A. D., and Howorth, P. J. N. (1972). Standardization of clinical enzyme assays. (Letter to the Editor). J. clin. Path., 25,

Moss, D. W., Baron, D. N., Walker P. G., and Wilkinson, J. H. (1971). Standardization of clinical enzyme assays. J. clin. Path., 24, 740-743.

[We have given the authors this opportunity to reply to the criticisms of Hirst and Howorth and King et al.-_EDITOR]

\section{Abbreviations for Names of Diagnostic Importance}

A recent communication (Baron, Moss, Walker, and Wilkinson, 1971) is disturbing inasmuch as the group, although representatives of specified organizations, was acting without the authority of these bodies. In addition, the authors state that although the International Union of Biochemistry (1961, 1965) strongly discouraged the use of abbreviations for enzymes, and that this was still upheld, they nevertheless arbitrarily continue, 'we recommend ....'

The pitfalls of abbreviations have been discussed elsewhere (King, 1969). The system put forward by Baron et al differentiates glutamate dehydrogenase and glutathione reductase as GMD and GTD respectively, but what happens to glycerate dehydrogenase and glyoxalate reductase? Alcohol dehydrogenase is AD, and presumably adenosine deaminase would be ADS, trypsin is TPS, and triose phosphate isomerase, TPI. It becomes easier to remember and use the trivial name than the abbreviation and it requires little imagination to see what the computer-controlled data processing systems mentioned would do with some of these abbreviations.

A second communication from this group (Moss, Baron, Walker, and Wilkinson, 1971) deals with the 'standardization' of alkaline phosphatase assay and a further report on the standardization of aspartate and alanine transaminase is promised. This raises the problem of how many standardizations the world can expect, since the German Society of Clinical Chemistry (1970) have already published their standard assays for the transaminases, alkaline phosphatase, lactate dehydrogenase, 2-hydroxybutyrate dehydrogenase, creatine kinase, and 'leucine arylamidase'. The situation is even more complicated because the London group state that an 'expert panel' of the International Federation of Clinical Chemists has the same subject under discussion.

Doubtless it is natural progression from the first report which discredits recommendations made by an international representative and authorized body to the later reports which disqualify such proposals before they are even made.

\section{J. KING \\ A. R. HENDERSON M. MCQUEEN \\ Department of Biochemistry, Royal Infirmary, Glasgow}

References

Baron, D. N., Moss, D. W., Walker, P. G., and Wilkinson, J. H. (1971). Abbreviations for names of enzymes of diagnostic importance. J. clin. Path., 24, 656-657.

German Society for Clinical Chemistry (1970). Standardisation of methods for the estimation of enzyme activity in biological fluids. Z. klin. Chem., 8, 658-660.

International Union of Biochemistry (1961). Report of the Commission on Enzymes, p. 33. Pergamon Press, Oxford.

International Union of Biochemistry (1965). Enzyme Nomenclature, p. 31. Elsevier, Amsterdam.

King, J. (1969). The nomenclature of enzymes and methods of expressing results. Brit. $J$. Anaesth., 41, 222-226.

Moss, D. W., Baron, D. N., Walker, P. G., and Wilkinson, J. H. (1971). Standardization of clinical enzyme assays. J. clin. Path., 24, 740-743.

\section{Correction}

We regret that the list of references, now set out below, was not printed with the Letter to the Editor, "A red herring in the detection of Bence Jones protein', by R. B. Payne (J. clin. Path., 25, 183).

\section{References}

Hobbs, J. R. (1966). The detection of Bence-Jones proteins. Biochem. J., 99, 15 P.

Hobbs, J. R. (1971). Immunocytoma o' mice an' men. Brit. med. J., 2, 67-72.

Jones, H. B. (1847). Papers on chemical pathology. Lecture III. Lancet, 2, 88-92.

Putnam, F. W., Easley, C. W., Lynn, L. T., Ritchie, A. E., and Phelps, R. A. (1959). The heat precipitation of Bence-Jones proteins. I. Optimum conditions. Arch. Biochem., 83, 115-130.

Whitehead, T. P., and Worthington, S. (1961). The determination of carboxyhaemoglobin. Clin. chim. Acta, 6, 356-359.

\section{Book reviews}

Reference Methods for the Microbiologicag Examination of Foods. (Report prepared by the Subcommittee on Food Microbiology of the Food Protection Committee $\Phi$ (Pp. 39. \$2.25.) Washington, DC: Nationat Academy of Sciences. 1971.

This booklet could be useful although is incomplete. There is no mention of this surface plate count and its advantages of the importance of anaerobic counts. Theres is no section on the isolation of Clos tridium welchii (perfringens) which figured highly in both UK and USA statistics foD food poisoning.

All the methods given appear i $\vec{\not}$ 'Microorganisms in foods' by the Intero national Committee on Microbiologicaf Specifications for Foods.

Many media are available for the isola tion and enumeration of coagulasepositive staphylococci so surely a referenco method could have been chosen but ne information is given.

In the salmonella section there is n\& guidance on the preparation of samples The beneficial effect of incubation at $43^{\circ} \mathrm{C}$ for some liquid enrichment media is not given.

Methods for faecal streptococci, Vibri parahaemolyticus, and Bacillus cereus are. not given, but there is a clear descriptions. of the serological identification of the enteropathogenic $E$. coli.

BETTY C. HOBB⿱二厶欠

Laboratory Diagnosis of Diseases Caused by Toxic Agents Edited by $F$. WP Sunderman, and F. W. Sunderman, J (Pp. xvii + 592; illustrated. £12.60. St. Louis, Missouri: Warren H. GreenN 1970. London: Adam Hilger Ltd. 1971.

This book contains the edited proceeding of an applied seminar held under the auspices of the Association of Clinicar Scientists in March 1970. The book if divided into four parts: 'General toxis? cological considerations', 'General metho: dological considerations', 'Specific toxig' agents', and 'Clinicopathologic consider $\bar{\Phi}^{+}$ ations'. Fifty-five papers are presented over a very wide toxicological field. Papers range from mode of action of poisonso metabolism, toxicity of food additives 